\title{
Effects of Corn Straw Biochar Application on Soybean Growth and Alkaline Soil Properties
}

\author{
Defu Liu, ${ }^{\text {a,b }}$ Zhenyue Feng, ${ }^{\mathrm{a}}$ Hongde Zhu, ${ }^{\mathrm{a}, *}$ Lihe $\mathrm{Yu},{ }^{\mathrm{a}}$ Kejun Yang, ${ }^{\mathrm{a}}$ Song Yu, \\ Yifei Zhang, ${ }^{\text {a }}$ and Wei Guo ${ }^{\text {a }}$
}

\begin{abstract}
Pot experiments were conducted to investigate the impact of biochar loading level on soybean growth and physico-chemical properties of alkaline soil. Biochar derived from corn straw was mixed with alkaline soil at $0 \%, 2.5 \%, 5 \%$, and $10 \%$ loading levels and exposed to the natural elements. Soybean was used as the test crop. The results indicated that a single application of biochar positively and significantly improved soybean productivity and quality attributes of the tested alkaline soil. Soybean yield peaked at $5 \%$ loading level, but it declined at $10 \%$ loading. Applications of biochar at $5 \%$ and $10 \%$ loading significantly increased total soil porosity by $4.14 \%$ and $5.09 \%$, and decreased the soil $\mathrm{pH}$ value by 0.07 and 0.24 units, respectively. Biochar addition significantly increased water holding capacity, total organic carbon content, total nitrogen, Olsen$\mathrm{P}$, available potassium, and cation exchange capacity. The results indicated that applications of corn straw biochar to alkaline soil improved soybean growth and promoted the physico-chemical properties of alkaline soil. However, the negative effects of increased $\mathrm{C}: \mathrm{N}$ ratios and soil exchange sodium percentages at higher biochar loading levels should be taken into account when applying biochar as amendments to alkaline soils.
\end{abstract}

Keywords: Alkaline soil; Biochar; Plant growth; Soil properties

Contact information: a: Heilongjiang Bayi Agricultural University and Heilongjiang Engineering Technology Research Center for Crop Straw Utilization, Key Laboratory of Modern Agricultural Cultivation and Crop Germplasm Improvement of Heilongjiang Province, Daqing, 163319; b: Daqing Branches of Heilongjiang Academy of Agricultural Sciences, Heilongjiang, China, 163316;

* Corresponding author: dqnky2010@163.com

\section{INTRODUCTION}

The semi-arid areas in western Heilongjiang Province are located in the western part of the Songnen Plain and collectively make up the largest soda saline-alkali area in China (Wang et al. 1993). The saline-alkali land area has now reached 3.937 million ha (Sun and Wang 2016). The soda saline-alkali soil in this area has a high $\mathrm{pH}$ value, and the main salts include $\mathrm{Na}_{2} \mathrm{CO}_{3}$ and $\mathrm{NaHCO}_{3}$. Most of the land in this area is alkaline and is one of the most important commodity grain and animal husbandry production bases in China. The main crop in this area is corn. The area has low natural precipitation and it is unevenly distributed. Low water retention and soil organic matter levels have always been the main restricting factors on agricultural development in this area, and they ultimately restrict local agricultural production and ecological restoration (Lai et al. 2014). At the same time, the environmental pollution caused by corn straw burning has brought about serious debate, and crops residues are difficult to be decomposed after being returned to the fields, which usually results in the reduced emergence rates for next season crops. This means that the utilization of straw resources is becoming more important. There are 
growing demands to revise the agricultural management strategy to enhance soil nutrient recycling, nutrient supply, and soil quality (Delate and Cambardella 2004; Lal 2006).

Recently, increased scientific attention has been paid to the use of biochar in ecological restoration and as a soil amendment because it has the potential to improve the physico-chemical and biological characteristics of soils (Yamato et al. 2006; Zhang et al. 2019a) and increase crop growth (Lehmann et al. 2003; Rajkovich et al. 2012; Arif et al. 2017).

Biochar is produced from the thermal decomposition of biomass under low oxygen conditions and is widely used as a soil amendment (Lehmann et al. 2006). The use of biochar in the current agricultural system has been emphasized as a promising strategy to improve nutrient utilization efficiency and enhance plant growth by improving soil physico-chemical properties and nutrient cycling (Lehmann et al. 2003; Laird et al. 2009; Spokas et al. 2012). Singh et al. (2010) revealed that high porosity within biochar usually leads to increased water holding capacity (WHC). Furthermore, biochar-modified soils have higher moisture retention levels, which help increase crop productivity and reduce irrigation frequency or intensity (Sohi et al. 2009). A meta-analysis by Jeffery et al. (2011) indicated that the benefit of biochar amendment on crop productivity ranged from $-28 \%$ to $39 \%$, with a $10 \%$ mean increase in tropical and subtropical regions. A field experiment conducted by Arif et al. (2017) indicated that biochar application increased wheat and maize grain yields by $18 \%$ and $24 \%$, respectively, compared to the control with no biochar addition. Uzoma et al. (2011) also reported similar results and indicated that biochar addition enhanced maize yield compared to the control without biochar.

To date, most studies have focused on the effectiveness of adding biochar to acidic, highly weathered tropical and subtropical soils, especially infertile acidic soils. These benefits can be attributed to the high biochar $\mathrm{C}$ content and cation exchange capacity (CEC). However, either no knowledge or less detailed knowledge is available regarding the effect of adding biochar to temperate soils, especially temperate and infertile alkaline soils. Numerous reports have confirmed the improvements in water retention and soil fertility after biochar application, making biochar a possible conditioner for alkaline soils in the semi-arid area of the Western Songnen Plain. The Songnen Plain is located in a semiarid region, and most of the soils in this area are alkaline with $\mathrm{pH}$ values ranging from 7.8 to 8.5 or higher. It has been suggested that the increase in $\mathrm{pH}$ values after biochar application to alkaline soil may result in negative impacts on soil characteristics and plant production.

In this study, pot trials were conducted to evaluate the impact of biochar on soybean growth and soil properties. Pot trials are beneficial to accurately assess the effects of experimental factors and the results of pot trials tend to have good regularity. However, the results of short-term pot trials lack practical and instructive value. Methodologies that integrate field trials with pot trials could improve their practical and instructive value (Jeffery et al. (2011).

The objectives of the current research were to determine the impact of biochar amendment on soybean growth and alkaline soil properties, and to evaluate the agricultural potential of biochar as a soil amendment for alkaline soils in semi-arid regions. This study can also be used in conjunction with the field-scale experiments to confirm any observations that can be further developed into future projects. 


\section{EXPERIMENTAL}

\section{Materials}

The soil samples used in this study were obtained from a plow layer with a depth of $0 \mathrm{~cm}$ to $15 \mathrm{~cm}$ and without organic litter at the Heilongjiang Bayi Agricultural University experimental area, which is located in Daqing, Heilongjiang, China $\left(46^{\circ} 62^{\prime} \mathrm{N}, 125^{\circ} 19^{\prime} \mathrm{E}\right.$, $146 \mathrm{mH})$. The soil was a typical alkaline soil.

The biochar was purchased from Liaoning Jinhefu Agricultural Development Co., Ltd. (Anshan, China) and was produced from the thermal decomposition of corn straw at a temperature of approximately $450{ }^{\circ} \mathrm{C}$ for $2 \mathrm{~h}$. Detailed information about the biochar manufacturing method can be found in the Chinese patent CN102092709B (Chen et al. 2012). The biochar was ground and filtered before it was used as amendment. The characteristics of the alkaline soil and biochar are shown in Table 1.

Table 1. Characteristics of Alkaline Soil and Biochar

\begin{tabular}{ccc}
\hline Properties & Alkaline Soil & Biochar \\
\hline pH & 8.25 & 7.94 \\
Total Carbon Content $(\mathrm{g} / \mathrm{kg})$ & - & 715 \\
Total Nitrogen Content $(\mathrm{g} / \mathrm{kg})$ & - & 15.35 \\
Total P Content $(\mathrm{g} / \mathrm{kg})$ & - & 7.82 \\
Total K Content $(\mathrm{g} / \mathrm{kg})$ & - & 16.82 \\
Alkali-hydrolyzed N $(\mathrm{g} / \mathrm{kg})$ & 127.70 & - \\
Olsen-P $(\mathrm{g} / \mathrm{kg})$ & 10.06 & - \\
Available K $(\mathrm{g} / \mathrm{kg})$ & 162.60 & - \\
Organic matter $(\%)$ & 2.89 & - \\
\hline
\end{tabular}

\section{Methods}

Treatments

The trial was set up in open-air conditions using plastic pots that were $290 \mathrm{~mm}$ in height and $145 \mathrm{~mm}$ in inner diameter. The biochar was applied at levels of $0 \%, 2.5 \%, 5 \%$, and $10 \%(\mathrm{w} / \mathrm{w})$. It was thoroughly mixed into the alkaline soil, and the mix was used to fill the pots. Each treatment, including the un-amended controls $(\mathrm{CK})$, was repeated four times. A drain hole under the pots was plugged with nylon mesh to prevent soil loss due to irrigation and rainfall, and water in the pots was allowed to drain freely. Each pot contained $20 \mathrm{~kg}$ of dried soil plus additions and reached a depth of approximately $220 \mathrm{~mm}$. Soybean (variety: Kennong 18; Heilongjiang Bayi Agricultural University, Daqing, China) was selected as the test plant, and adequate water was added to maintain field capacity at $85 \%$. A total of 10 seeds were sown at a depth of $25 \mathrm{~mm}$ on May $20^{\text {th }}, 2017$. After soybean emergence, each pot was thinned to three plants and a regular watering schemes was implemented twice a week to minimize plant water stress. The soils moisture content was adjusted to $60 \%$ of the maximum water holding capacity by weight during the soybean growth season. All treatments received standard fertilizer at an application dosage of $45 \mathrm{~kg} / \mathrm{ha}$ for urea (Luxi/N 46.4\%, Luxi Chemical Co., Ltd., Shandong, China), $135 \mathrm{~kg} / \mathrm{ha}$ for diammonium phosphate (Sinochem $/ \mathrm{P}_{2} \mathrm{O}_{5} 46 \%$, Sinochem Fertilizer Holdings Co., Ltd., Beijing, China), and $60 \mathrm{~kg} / \mathrm{ha}$ for potassium sulfate $\left(\mathrm{K}_{2} \mathrm{O} 50 \%\right.$, Zhongnong International Fertilizer Import and Export Group Yantai Co., Ltd., Shandong, China). 


\section{Sample collection and measurement}

After 5 months of growth, the seeds and vegetative plant parts of the soybean were harvested, dried, and separately weighed. The results were scaled up to $\mathrm{kg} / \mathrm{ha}$ according to the pot surface area $\left(660 \mathrm{~cm}^{2}\right)$. Leaf chlorophyll content was measured using an Minolta SPAD-502 chlorophyll meter (Minolta Camera Co., Ltd., Osaka, Japan) during preflowering stage (60 d after sowing, DAS). Soil samples were taken at different soybean growth stages (seeding stage, early bloom stage, full bloom stage, pod stage, and harvest) from the pots for physical and chemical measurements. Bulk density (BD) was evaluated from samples taken from the $0 \mathrm{~cm}$ to $15 \mathrm{~cm}$ soil layer using metal cylinders. The soil samples were dried and weighed at $105^{\circ} \mathrm{C}$ until they reached a constant weight. The total porosity was calculated using the following formula: Total porosity $(\%)=(1-$ bulk density/particle density) $\times 100$ (particle density (PD) $2.65 \mathrm{Mg} / \mathrm{m}^{3}$ ).

The water holding capacity was measured as follows: a soil sample of $10 \mathrm{~g}$ was weighed and placed in a plastic cylinder with nylon mesh at the bottom. The cylinder was then placed in water. After $24 \mathrm{~h}$, the water in the water-saturated soil was allowed to drain until there was no water release, and then the sample was weighed again to calculate the soil water holding capacity. The soil $\mathrm{pH}$ and $\mathrm{EC}$ were measured with a soil-to- $\mathrm{CaCl}_{2}$ ratio $(0.01 \mathrm{~mol} / \mathrm{L})$ of $1: 5(\mathrm{w} / \mathrm{v})$ and were analyzed by a $\mathrm{pH}$ meter (PHS-3C; Shanghai Precision \& Instrument Co., Ltd., Shanghai, China) and a portable multiparameter analyzer (DZB718; Shanghai Leici Instrument Co., Ltd., Shanghai, China). Total organic carbon (TOC) and total organic nitrogen (TON) in the soil were determined by dry combustion on a VarioMax CN analyzer (Elementar, Hanau, Germany). Cation exchange capacity (CEC) was measured using the NaOAc exchange and flame luminosity methods described by Lu (2000). Olsen-P was estimated using the $0.5 \mathrm{M} \mathrm{NaHCO}_{3}$ method described by $\mathrm{Bao}$ (2007). Available potassium (AK) was measured using flame atomic absorption spectrophotometer methods described by Lu (2000). Exchangeable sodium percentage (ESP) was calculated according to Eq. 1:

$$
\mathrm{ESP}=\text { exchangeable sodium content / cation exchange capacity }
$$

\section{Statistical analysis}

All statistical analyses were performed using SPSS V 21.0 software (IBM, Armonk, NY, USA). The data were analyzed by a one-way analysis of variance (ANOVA) followed by Duncan's post hoc procedure.

\section{RESULTS AND DISCUSSION}

\section{Effects of Biochar Application on Soybean Growth and Yield Components}

Biochar incorporation enhanced soybean growth and yield components compared to the control with no biochar addition. Significantly positive effects relative to soybean height and biomass were observed, and the highest soybean height, biomass, and yield were obtained at the 5\% biochar loading. Biochar loading also had a significant effect on soybean pod number per plant, soybean seed number per plant, soybean 100-seed weight, soybean seed yield, and harvest index (HI) (Table 2). Biochar application significantly increased pod number per plant, number of soybean seeds per plant, 100-seed weight, and seed yield. The highest yield was obtained at the 5\% biochar loading, whereas the $10 \%$ 
biochar loading level slightly decreased soybean seed and biomass yields. The HI significantly increased for all treatments when biochar was added to the soil.

Table 2. Effects of Biochar Loading Levels (0\%, 2.5\%, $5 \%$, and $10 \%$ ) on Soybean Biomass Production and Yield Components

\begin{tabular}{|c|c|c|c|c|c|c|c|}
\hline $\begin{array}{c}\text { Biochar } \\
\text { Treatment }(\%, \\
\text { w/w) }\end{array}$ & $\begin{array}{c}\text { Height } \\
(\mathrm{cm})\end{array}$ & $\begin{array}{c}\text { Pod } \\
\text { Number }\end{array}$ & $\begin{array}{c}\text { Seed } \\
\text { Number }\end{array}$ & $\begin{array}{c}100-\text { seed } \\
\text { Weight } \\
(\mathrm{g})\end{array}$ & $\begin{array}{c}\text { Seed Yield } \\
(\mathrm{kg} / \mathrm{ha})\end{array}$ & $\begin{array}{c}\text { Biomass } \\
(\mathrm{kg} / \mathrm{ha})\end{array}$ & $\begin{array}{c}\text { Harvest } \\
\text { Index }\end{array}$ \\
\hline $0 \%$ & $87.6 \mathrm{c}$ & $13.97 \mathrm{c}$ & $35.52 \mathrm{c}$ & $21.59 \mathrm{c}$ & $2485 \mathrm{c}$ & $4060.6 \mathrm{c}$ & $61.20 \mathrm{c}$ \\
\hline $2.5 \%$ & $89.1 \mathrm{~b}$ & $14.63 \mathrm{~b}$ & $37.38 \mathrm{ab}$ & $21.96 \mathrm{~b}$ & $2621 \mathrm{~b}$ & $4161.6 \mathrm{~b}$ & $61.29 \mathrm{c}$ \\
\hline $5.0 \%$ & $92.4 \mathrm{a}$ & $15.84 \mathrm{a}$ & $37.25 \mathrm{~b}$ & $22.56 \mathrm{a}$ & $2758.5 \mathrm{a}$ & $4389.2 \mathrm{a}$ & $62.98 \mathrm{a}$ \\
\hline $10 \%$ & $91.2 \mathrm{~b}$ & $14.74 \mathrm{~b}$ & $37.97 \mathrm{a}$ & $22.52 \mathrm{a}$ & $2673 \mathrm{~b}$ & $4361.2 \mathrm{ab}$ & $62.84 \mathrm{~b}$ \\
\hline
\end{tabular}

Different letters indicate statistical differences at $p<0.05(n=4)$

\section{Effects of Biochar Application on Alkaline Soil Bulk Density, Soil Porosity, and Water Holding Capacity}

Table 3 shows that biochar application significantly decreased soil bulk density, but it enhanced soil total porosity, saturated soil water content, and water holding capacity. The bulk density decreased $6.7 \%$ at the $10 \%$ biochar loading compared to the control. The total soil porosity in the 5\% and $10 \%$ biochar treatments increased $4.14 \%$ and $5.09 \%$, respectively, compared to the control. The saturated water content in the $2.5 \%, 5 \%$, and $10 \%$ treatments increased $2.75 \%, 5.09 \%$, and $6.61 \%$ compared to the control treatment (Table 3), respectively. Water holding capacity significantly increased from $32.3 \%$ in the control treatment to $34.2 \%$ and $34.6 \%$ in the $5 \%$ and $10 \%$ treatments $(\mathrm{p}<0.05$ ), respectively, which represented an increase of $6.00 \%$ and $7.12 \%$, respectively. There were no differences between the $0 \%$ and $2.5 \%$ treatments or between the $2.5 \%$ and $5 \%$ treatments.

Table 3. Effects of Biochar Loading Levels on Bulk Density, Soil Porosity, and Water Holding Capacity

\begin{tabular}{|c|c|c|c|c|}
\hline $\begin{array}{c}\text { Biochar } \\
\text { Treatment } \\
(\mathrm{w} / \mathrm{w})\end{array}$ & $\begin{array}{c}\text { Bulk Density } \\
\left(\mathrm{g} / \mathrm{cm}^{3}\right)\end{array}$ & $\begin{array}{c}\text { Total Soil } \\
\text { Porosity } \\
\left(\mathrm{cm}^{3} \cdot \mathrm{cm}^{-3}\right)\end{array}$ & $\begin{array}{c}\text { Saturated Water } \\
\text { Content } \\
\left(\mathrm{cm}^{3} \cdot \mathrm{cm}^{-3}\right)\end{array}$ & $\begin{array}{c}\text { Water Holding } \\
\text { Capacity } \\
\left(\mathrm{cm}^{3} \cdot \mathrm{cm}^{-3}\right)\end{array}$ \\
\hline $0 \%$ & $1.26 \pm 0.04 \mathrm{a}$ & $52.67 \pm 2.01 \mathrm{c}$ & $44.01 \pm 1.11 \mathrm{c}$ & $32.31 \pm 1.21 \mathrm{~b}$ \\
\hline $2.5 \%$ & $1.23 \pm 0.02 \mathrm{~b}$ & $53.18 \pm 2.41 \mathrm{~b}$ & $45.22 \pm 0.96 \mathrm{bc}$ & $33.42 \pm 0.91 \mathrm{~b}$ \\
\hline $5.0 \%$ & $1.22 \pm 0.03 \mathrm{~b}$ & $54.85 \pm 2.75 \mathrm{ab}$ & $46.25 \pm 1.32 \mathrm{~b}$ & $34.25 \pm 1.85 \mathrm{a}$ \\
\hline $10 \%$ & $1.18 \pm 0.02 \mathrm{c}$ & $55.35 \pm 3.21 \mathrm{a}$ & $46.91 \pm 1.05 \mathrm{a}$ & $34.61 \pm 2.41 \mathrm{a}$ \\
\hline
\end{tabular}

Note: Values are means of four replications \pm standard deviation (SD); different letters indicate statistical differences at $p<0.05(n=4)$

\section{Effects of Biochar Application on Alkaline Soil pH and Electrical Conductivity}

The soil $\mathrm{pH}$ values and electrical conductivities (EC) after 5 months of incubation are shown in Fig. 1. Soil pH value showed a decreasing trend as the biochar loading levels increased. It decreased from 8.25 in the control treatment to 8.18 and 8.01 in the $5 \%$ and $10 \%$ treatments $(\mathrm{p}<0.05)$, respectively. The $10 \%$ biochar treatment showed the largest $\mathrm{pH}$ decrease, which was 0.24 , whereas the $\mathrm{pH}$ in the $2.5 \%$ biochar treatment only decreased 0.03. The soil EC showed an increasing trend as the biochar loading rose, except that the

Liu et al. (2020). "Biochar vs. alkaline soil \& soybean," BioResources 15(1), 1463-1481. 1467 
5\% biochar treatment EC decreased to some extent. The $10 \%$ treatment showed the largest EC increase, which was $26 \mu \mathrm{S} / \mathrm{cm}$.

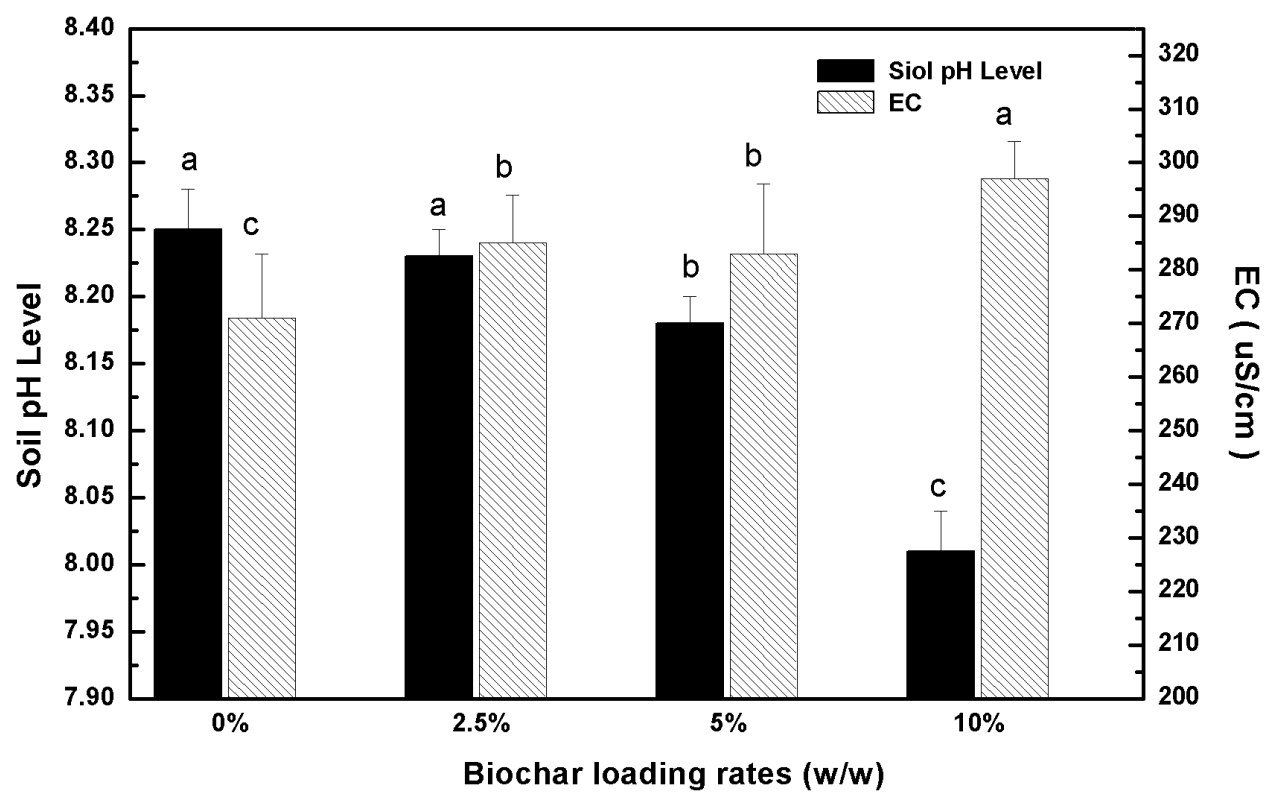

Fig. 1. Effects of biochar loading $(0 \% \mathrm{w} / \mathrm{w}, 2.5 \% \mathrm{w} / \mathrm{w}, 5 \% \mathrm{w} / \mathrm{w}$, and $10 \% \mathrm{w} / \mathrm{w})$ on soil $\mathrm{pH}$ and $\mathrm{EC}$; bars are the means of the replicates \pm standard error of the mean $(n=4)$

\section{Effects of Biochar on Alkaline Soil TOC, Soil TON, and the C:N Ratio}

Table 4 shows that biochar amendment significantly influenced the soil total organic carbon content at all five soybean growth stages. The 5\% and $10 \%$ biochar treatments significantly increased soil total organic carbon content across the whole growth season compared to the control treatment. The $2.5 \%$ biochar treatment showed varying degrees of increase in soil total organic carbon content. There were no significant effects during the soybean early bloom and full bloom stages compared to the control treatment. Additionally, TOC content first increased and then decreased for the same treatment as the growth season progressed.

Table 4. Effects of Biochar Loading Levels on Soil Organic Carbon during the Soybean Growth Season

\begin{tabular}{|c|c|c|c|c|c|}
\hline \multirow{2}{*}{$\begin{array}{l}\text { Biochar } \\
\text { Treatment } \\
\text { (w/w) }\end{array}$} & \multicolumn{5}{|c|}{ Soil Total Organic Carbon Content (g/kg) } \\
\hline & Seeding & Early Bloom & Full Bloom & Pod & Maturity \\
\hline $0 \%$ & $15.60 \pm 0.60 c$ & $17.29 \pm 0.77 b$ & $21.02 \pm 0.65 c$ & $17.52 \pm 0.78 \mathrm{c}$ & $15.87 \pm 0.55 c$ \\
\hline $2.5 \%$ & $18.27 \pm 0.45 b$ & $18.35 \pm 0.32 b$ & $22.08 \pm 0.5 b c$ & $20.73 \pm 0.81 \mathrm{~b}$ & $16.96 \pm 0.99 b$ \\
\hline $5.0 \%$ & $22.80 \pm 0.34 \mathrm{~b}$ & $23.17 \pm 0.35 a$ & $23.97 \pm 1.57 b$ & $24.16 \pm 1.67 \mathrm{a}$ & $20.17 \pm 0.62 \mathrm{a}$ \\
\hline $10 \%$ & $26.55 \pm 0.48 a$ & $26.22 \pm 0.89 a$ & $27.56 \pm 0.63 a$ & $26.22 \pm 2.45 \mathrm{a}$ & $21.97 \pm 0.20 a$ \\
\hline
\end{tabular}

Different letters indicate statistical differences at $p<0.05(n=4)$

Table 5 shows that biochar had a significant impact on soil total nitrogen during different growth stages. The 5\% and $10 \%$ biochar treatments significantly increased soil total nitrogen content across the whole growth season compared to the control treatment, but no differences were observed between the $0 \%$ and $2.5 \%$ biochar treatments from the 
soybean early blooming stage to the pod stage. The flowering and pod stages were the most vigorous periods for soybean growth and development, and they were the key fertilizer requirement periods during soybean growth. The total nitrogen content in the 5\% and $10 \%$ biochar treatments during the flowering stage increased $3.8 \%$ and $13.2 \%$, respectively, and $17.1 \%$ and $12.9 \%$ during the pod stage, respectively, but either no increase or a low increase was observed in the $2.5 \%$ biochar treatment during these periods.

Table 5. Effects of Biochar Loading Levels on Soil Total Nitrogen during the Soybean Growth Season $(\mathrm{g} / \mathrm{kg})$

\begin{tabular}{|c|c|c|c|c|c|}
\hline \multirow{2}{*}{$\begin{array}{l}\text { Biochar } \\
\text { Treatment } \\
\text { (w/w) }\end{array}$} & \multicolumn{5}{|c|}{ Soil Total Nitrogen Content ( $\mathrm{g} / \mathrm{kg})$} \\
\hline & Se & oom & Full Bloom & Pod & rity \\
\hline $0 \%$ & $1.56 \pm$ & $1.73 \pm 0.44 c$ & $2.13 \pm 0.32 c$ & $1.94 \pm 0.41 c$ & 1.87 \\
\hline $2.5 \%$ & $1.61 \pm 0.31 b$ & $1.82 \pm 0.28 \mathrm{c}$ & $2.14 \pm 0.32 \mathrm{c}$ & $1.94 \pm 0.23 c$ & $1.96=$ \\
\hline $5.0 \%$ & $1.87 \pm 0.21 \mathrm{a}$ & $1.98 \pm 0.41 \mathrm{~b}$ & $2.21 \pm 0.48 \mathrm{ab}$ & $2.12 \pm 0.32 b$ & $2.01 \pm 0.42 b$ \\
\hline $10 \%$ & $1.91 \pm 0.44 a$ & $2.16 \pm 0.36 a$ & $2.26 \pm 0.27 a$ & $2.27 \pm 0.27 \mathrm{a}$ & $2.04 \pm 0.38 a$ \\
\hline
\end{tabular}

Different letters indicate statistical differences at $p<0.05(n=4)$

Biochar application significantly altered soil total organic carbon and total nitrogen contents, which affected the soil C:N ratio. Table 6 shows that the soil C:N ratios were significantly higher in the biochar treatments than in the control treatment during the different growth periods, especially for the $10 \%$ biochar treatment. The treatments increased the C:N ratios 39\%, 27.8\%, 24.2\%, 27.9\%, and 20.4\%, respectively. The higher $\mathrm{C}: \mathrm{N}$ ratios might have contributed to the decline in soybean yield in the $10 \%$ biochar treatment compared to the $5 \%$ biochar treatment because nitrogen availability decreased at the higher $\mathrm{C}: \mathrm{N}$ ratios produced by the $10 \%$ biochar loading level.

Table 6. Effects of Biochar Loading Levels on soil C:N Ratio

\begin{tabular}{|c|c|c|c|c|c|}
\hline \multirow{2}{*}{$\begin{array}{l}\text { Biochar } \\
\text { Treatment } \\
(\mathrm{w} / \mathrm{w})\end{array}$} & \multicolumn{5}{|c|}{ Soil $\mathrm{C} / \mathrm{N}$} \\
\hline & Seeding & Early Bloom & Full Bloom & Pod & Maturity \\
\hline $0 \%$ & $10.01 \pm 0.32 \mathrm{~d}$ & $9.50 \pm 0.48 d$ & $9.82 \pm 0.32 c$ & $9.03 \pm 0.41 c$ & $8.49 \pm 0.37 d$ \\
\hline $2.5 \%$ & $11.61 \pm 0.33 c$ & $10.61 \pm 0.24 c$ & $10.36 \pm 0.32 b$ & $10.69 \pm 0.23 b$ & $8.65 \pm 0.42 c$ \\
\hline $5.0 \%$ & $12.19 \pm 0.21 b$ & $11.79 \pm 0.41 b$ & $10.85 \pm 0.48 b$ & $11.39 \pm 0.32 \mathrm{a}$ & $10.03 \pm 0.42 b$ \\
\hline $10 \%$ & $13.90 \pm 0.44 a$ & $12.14 \pm 0.36 \mathrm{a}$ & $12.19 \pm 0.27 \mathrm{a}$ & $11.55 \pm 0.27 \mathrm{a}$ & $10.22 \pm 0.38 a$ \\
\hline
\end{tabular}

\section{Effects of Biochar Application on Soil Available Nitrogen, Available Phosphorus, and Available Potassium}

Figure 2 shows that biochar application significantly decreased the soil available nitrogen content during different growth stages. The $10 \%$ biochar treatment showed the maximum reduction, as it decreased $10.95 \%$ compared to the control treatment at the pod stage. The decreases in soil available nitrogen content were highly consistent with reduction in leaf SPAD values (data not shown).

Figure 3 shows that the biochar amendment increased soil available phosphorus content during the different growth stages. The 5\% and $10 \%$ biochar treatments significantly increased soil available phosphorus content compared to the control treatment, and soil available phosphorus generally increased in proportion to biochar loading levels. After 5 months of incubation, the available phosphorus content in the $2.5 \%$, 
$5 \%$, and $10 \%$ biochar treatments increased $23.7 \%, 29.2 \%$, and $32.9 \%$, respectively, compared to the control treatment. Additionally, the soil available phosphorus content also first increased, but then decreased for the same treatment as the growth season progressed.

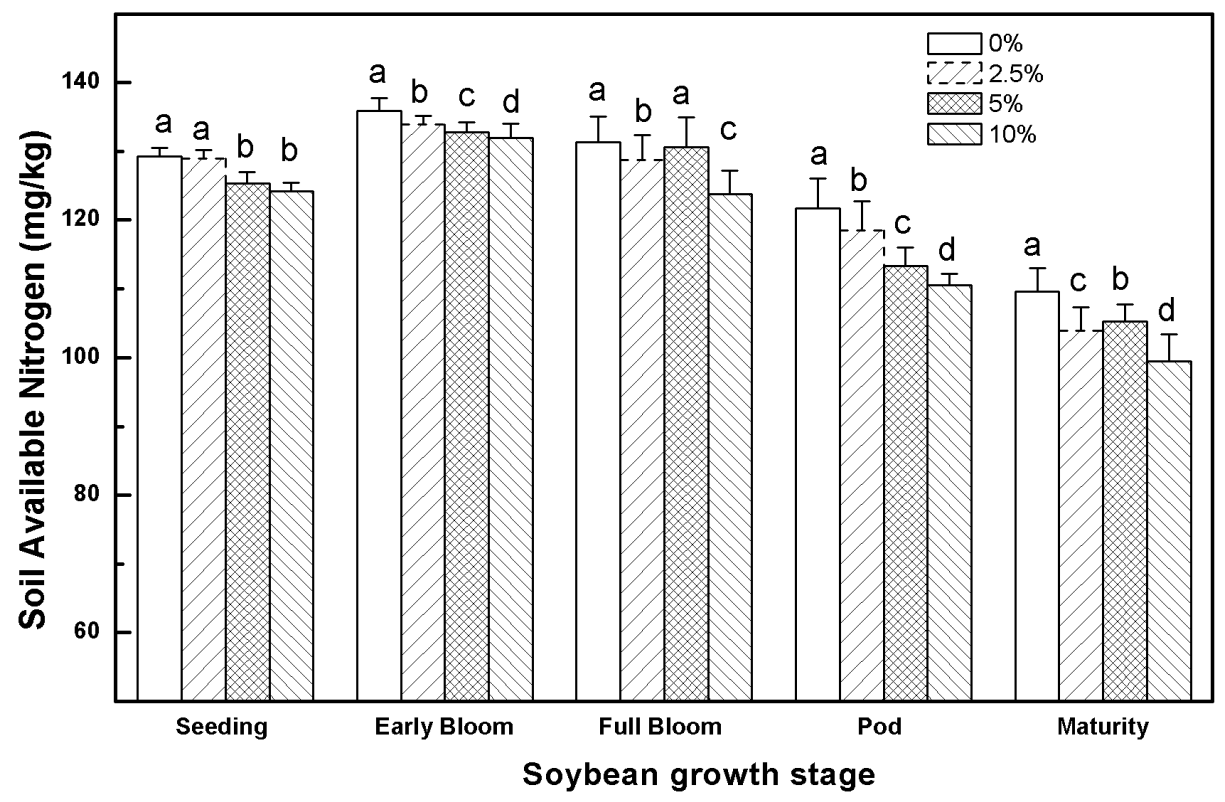

Fig. 2. Effects of biochar loading levels $(0 \% \mathrm{w} / \mathrm{w}, 2.5 \% \mathrm{w} / \mathrm{w}, 5 \% \mathrm{w} / \mathrm{w}$, and $10 \% \mathrm{w} / \mathrm{w})$ on soil available nitrogen; different letters indicate statistical differences at $p<0.05$

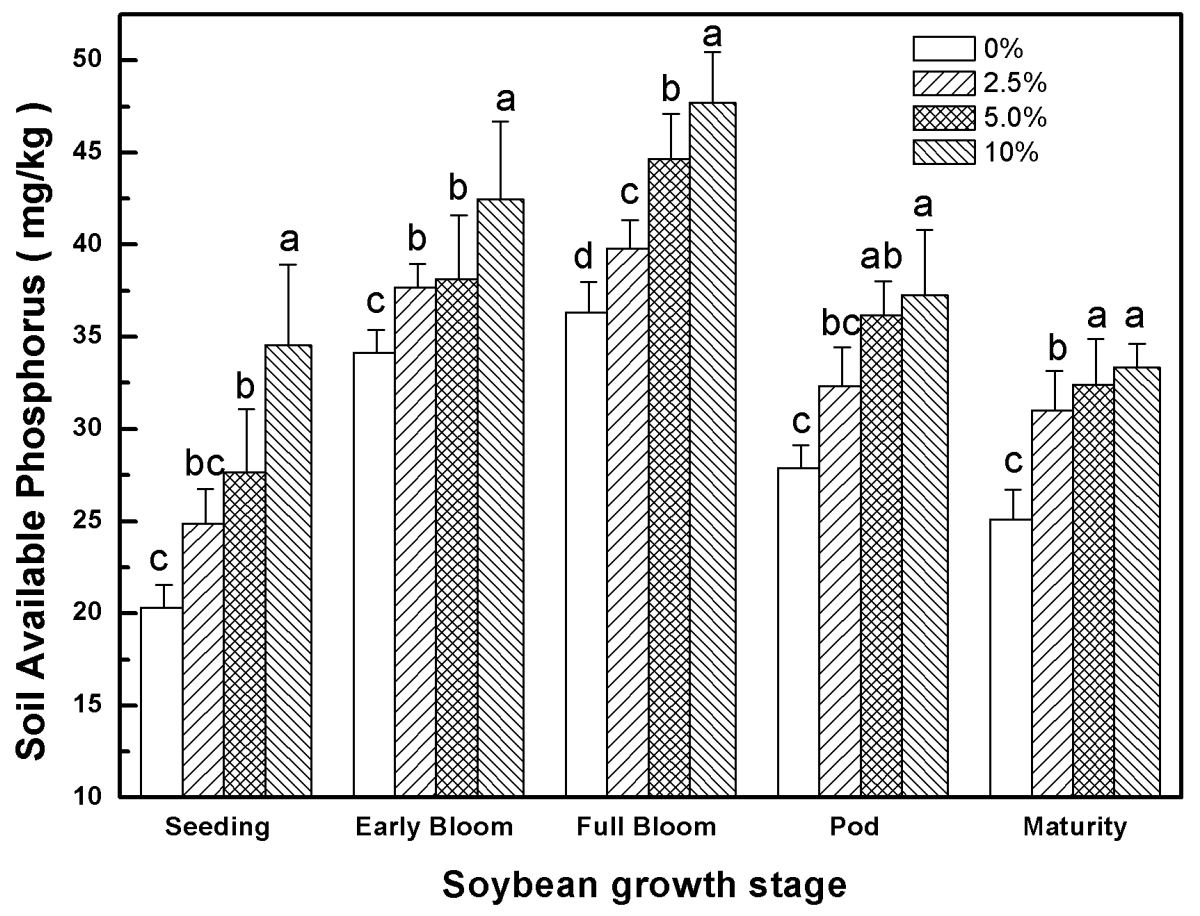

Fig. 3. Effects of biochar loading levels ( $0 \% \mathrm{w} / \mathrm{w}, 2.5 \% \mathrm{w} / \mathrm{w}, 5 \% \mathrm{w} / \mathrm{w}$, and $10 \% \mathrm{w} / \mathrm{w})$ on soil available phosphorus; different letters indicate statistical differences at $p<0.05$

Figure 4 shows that for each growth stage, the available potassium content in biochar-modified soil increased as the biochar loading levels increased, especially for the 
$5 \%$ and $10 \%$ treatments. There was either no difference or only a small difference from the full bloom stage to maturity stage between the $2.5 \%$ biochar treatment and the control treatment

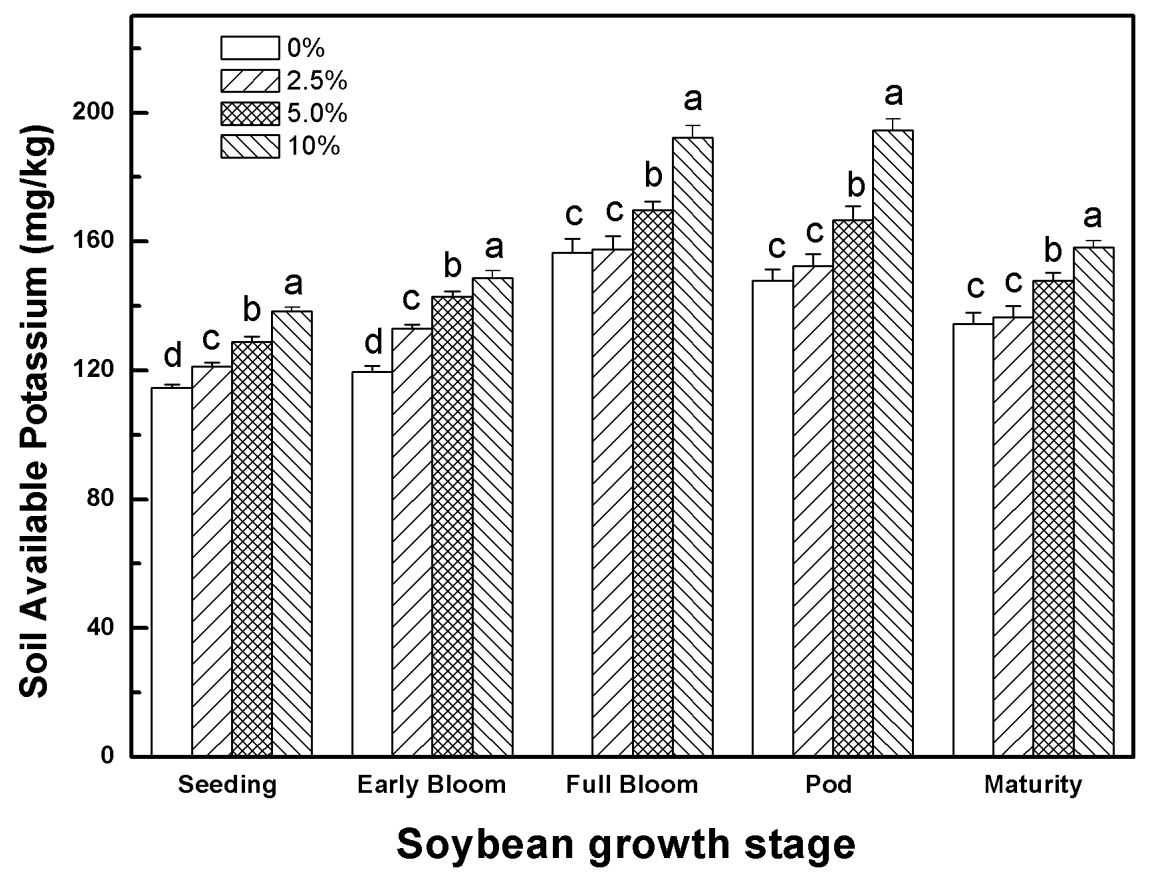

Fig. 4. Effects of biochar loading levels $(0 \% \mathrm{w} / \mathrm{w}, 2.5 \% \mathrm{w} / \mathrm{w}, 5 \% \mathrm{w} / \mathrm{w}, 10 \% \mathrm{w} / \mathrm{w})$ on soil available potassium; error bars represent the standard deviation $(n=4)$. Different letters indicate statistical differences at $p<0.05$.

\section{Effects of Biochar Application on Soil Exchangeable Cations ( $\mathrm{Ca}, \mathrm{Mg}$, and $\mathrm{Na}), \mathrm{CEC}$, and ESP}

Table 7 shows that biochar had either no effects or only small effects on the levels of exchangeable calcium and exchangeable magnesium. However, the exchangeable sodium increased significantly by $6.4 \%$ and $15.4 \%$ in the $5 \%$ and $10 \%$ treatments $(\mathrm{p}<$ 0.05), respectively. Biochar application also significantly increased the soil CEC levels, especially in the 5\% and $10 \%$ treatments where the CEC levels rose $6.61 \mathrm{cmol} / \mathrm{kg}$ and 8.26 $\mathrm{cmol} / \mathrm{kg}$, respectively. Soil ESP significantly decreased from $30.07 \%$ in the control to $23.81 \%$ and $25.19 \%$ in the $5 \%$ and $10 \%$ treatments, respectively.

Table 7. Effects of Biochar Loading Levels on Exchangeable Cations ( $\mathrm{Ca}, \mathrm{Mg}$, and $\mathrm{Na}$ ), Soil CEC, and ESP

\begin{tabular}{|c|c|c|c|c|c|}
\hline $\begin{array}{c}\text { Biochar } \\
\text { Treatment } \\
(\mathrm{w} / \mathrm{w})\end{array}$ & $\begin{array}{c}\text { Exc. Ca } \\
(\mathrm{cmol} / \mathrm{kg})\end{array}$ & $\begin{array}{c}\text { Exc. Mg } \\
(\mathrm{cmol} / \mathrm{kg})\end{array}$ & $\begin{array}{c}\text { Exc. Na } \\
(\mathrm{cmol} / \mathrm{kg})\end{array}$ & $\begin{array}{c}\text { CEC } \\
(\mathrm{cmol} / \mathrm{kg})\end{array}$ & ESP (\%) \\
\hline $0 \%$ & $0.46 \mathrm{a}$ & $0.43 \mathrm{a}$ & $5.78 \mathrm{c}$ & $19.22 \mathrm{c}$ & $30.07 \mathrm{a}$ \\
\hline $2.5 \%$ & $0.49 \mathrm{a}$ & $0.46 \mathrm{a}$ & $5.95 \mathrm{c}$ & $21.61 \mathrm{c}$ & $27.53 \mathrm{~b}$ \\
\hline $5.0 \%$ & $0.55 \mathrm{a}$ & $0.48 \mathrm{a}$ & $6.15 \mathrm{~b}$ & $25.83 \mathrm{~b}$ & $23.81 \mathrm{~d}$ \\
\hline $10 \%$ & $0.57 \mathrm{a}$ & $0.54 \mathrm{a}$ & $6.67 \mathrm{a}$ & $27.48 \mathrm{a}$ & $25.19 \mathrm{c}$ \\
\hline
\end{tabular}

Different letters indicate statistical differences at $p<0.05(n=4)$; CEC: cation exchange capacity, ESP: exchange sodium percentage; Exc: exchangeable 


\section{Correlation of Soil Characteristics with Soybean Growth and Yield Parameters}

The correlation analysis of the soil chemical properties with the soybean growth and yield parameters is shown in Table 8 . The results indicated that soil $\mathrm{pH}$, soil exchangeable sodium, soil available nitrogen, and soil exchangeable sodium percentage had significant or very significant negative correlations with soybean biomass production and yield parameters. The results additionally showed that soil $\mathrm{pH}$, soil exchangeable sodium, soil available nitrogen, and soil exchangeable sodium percentage had the greatest impact on the growth and development of soybeans under saline-alkaline soil conditions.

Table 8. Analysis of the Correlation between Soil Chemical Properties and the Soybean Growth and Yield Parameters

\begin{tabular}{|c|c|c|c|c|c|c|c|}
\hline & Height & $\begin{array}{c}\text { Pod } \\
\text { Number }\end{array}$ & $\begin{array}{c}\text { Seed } \\
\text { Number }\end{array}$ & $\begin{array}{c}\text { 100-seed } \\
\text { Weight }\end{array}$ & $\begin{array}{l}\text { Seed } \\
\text { Yield }\end{array}$ & Biomass & $\begin{array}{l}\text { Harvest } \\
\text { Index }\end{array}$ \\
\hline $\begin{array}{l}\text { Total Soil } \\
\text { Porosity }\end{array}$ & 0.701 & 0.37 & $0.823^{*}$ & 0.813 & 0.641 & 0.761 & -0.202 \\
\hline $\begin{array}{l}\text { Saturated } \\
\text { Water } \\
\text { Content }\end{array}$ & $0.803^{\star}$ & 0.617 & $0.814^{*}$ & $0.872^{* *}$ & $0.862^{*}$ & $0.805^{\star}$ & 0.124 \\
\hline $\begin{array}{l}\text { Water } \\
\text { Holding } \\
\text { Capacity }\end{array}$ & $0.812^{*}$ & 0.732 & $0.822^{*}$ & $0.827^{\star *}$ & $0.811^{*}$ & $0.826^{*}$ & 0.203 \\
\hline $\mathrm{pH}$ & -0.329 & -0.212 & $-0.321^{*}$ & -0.423 & -0.472 & -0.211 & 0.317 \\
\hline $\begin{array}{c}\text { Electric } \\
\text { Conductivity }\end{array}$ & 0.614 & 0.316 & $0.825^{\star}$ & 0.773 & 0.631 & 0.703 & 0.042 \\
\hline $\begin{array}{l}\text { Soil Organic } \\
\text { Carbon }\end{array}$ & 0.837 & 0.613 & 0.719 & $0.814^{*}$ & 0.782 & $0.804^{\star}$ & -0.072 \\
\hline $\begin{array}{c}\text { Total } \\
\text { Nitrogen }\end{array}$ & $0.820^{*}$ & 0.731 & $0.814^{*}$ & $0.861^{* *}$ & $0.892^{*}$ & $0.844^{*}$ & 0.251 \\
\hline $\mathrm{C} / \mathrm{N}$ & $-0.529^{*}$ & -0.421 & $-0.721^{* *}$ & $-0.723^{\star *}$ & $-0.522^{*}$ & $-0.674^{*}$ & $-0.711^{*}$ \\
\hline Exc. Ca & 0.718 & $0.819^{*}$ & 0.182 & 0.652 & 0.742 & 0.714 & 0.391 \\
\hline Exc. Mg & 0.623 & 0.217 & 0.681 & 0.752 & 0.492 & 0.724 & -0.324 \\
\hline Exc. $\mathrm{Na}$ & $-0.621^{*}$ & $-0.814^{* *}$ & -0.022 & -0.433 & $-0.632^{* *}$ & $-0.428^{*}$ & $-0.591^{*}$ \\
\hline $\begin{array}{l}\text { Cation } \\
\text { Exchange } \\
\text { Capacity }\end{array}$ & $0.821^{*}$ & 0.619 & $0.811^{*}$ & $0.717^{\star *}$ & 0.827 & $0.716^{*}$ & 0.156 \\
\hline $\begin{array}{c}\text { Exchange } \\
\text { Sodium } \\
\text { Percentage }\end{array}$ & $-0.731^{*}$ & -0.436 & $-0.828^{\star *}$ & $-0.813^{\star *}$ & $-0.721^{*}$ & $-0.772^{*}$ & -0.175 \\
\hline $\begin{array}{l}\text { Available } \\
\text { Nitrogen }\end{array}$ & -0.529 & -0.321 & $-0.724^{*}$ & -0.713 & -0.529 & -0.695 & -0.043 \\
\hline $\begin{array}{c}\text { Available } \\
\text { Phosphorus }\end{array}$ & 0.816 & 0.712 & $0.828^{* *}$ & $0.912^{*}$ & $0.902^{\star}$ & $0.839^{\star}$ & 0.414 \\
\hline $\begin{array}{c}\text { Available } \\
\text { Potassium }\end{array}$ & 0.709 & 0.418 & 0.715 & $0.818^{*}$ & 0.627 & 0.828 & -0.215 \\
\hline \multicolumn{8}{|c|}{ Note: ${ }^{*}=p<0.05 ;{ }^{* *}=p<0.01$} \\
\hline
\end{tabular}

\section{Impacts of Biochar on Soybean Biomass and Seed Yield}

Previous studies reported that biochar application can significantly promote crop biomass accumulation, growth and development, and grain yield (Steiner et al. 2007; Major et al. 2010; Farhangi-Abriz and Torabian 2018). Our studies indicated that biochar 
application promote the soybean growth and yield components. The similar results were also reported by $\mathrm{Wu}$ et al. (2019), who showed that amending red soil with biochar increased the number of effective cotton branches, bolls, and buds, and led to early bud formation. Increases in productivity after biochar application have also been recorded for other leguminous plants, such as alfalfa (Nishio and Okano 1991), common bean (Rondon et al. 2007), and clover (Quilliam et al. 2013; Mia et al. 2014). It has been widely accepted that biochar application affects plant growth and promotes crop yield by ameliorating soil physico-chemical characteristics, such as reductions in soil bulk density (Novak et al. 2009; Busscher et al. 2010; Laird et al. 2010), enhanced soil porosity (Baiamonte et al. 2015), water holding capacity (Liu et al. 2012a; Basso et al. 2013), and soil cation exchange capacity (Glaser et al. 2002; Rondon et al. 2007). Furthermore, nutrients contained within biochar and improvements in nutrient retention after biochar addition might account for the shortterm enhancement of crop productivities (Lehmann et al. 2003; Steiner et al. 2007). Apart from direct nutrient supply and retention within biochar, other possible mechanisms that contributed to increased crop yields after biochar application include changes in soil structure and nutrient status (Lin et al. 2018). Biochar also promotes nutrient uptake by improving soil microbial activity (Chan et al. 2008; Sohi et al. 2009). The experiment conducted by Zhang et al. (2019a,b) indicated that application of biochar had a much greater effect on bacteria community and alpha diversity in acid soils than in alkaline soils.

These results also showed that the excessive addition of biochar (10\% biochar loading) inhibited soybean growth. Similar results were also reported by Rondon et al. (2007), who showed that the yield of the common bean (P. vulgaris L.) was the highest at the $78 \mathrm{t} /$ ha biochar loading but decreased when the biochar loading exceeded this threshold. In this experiment, the available nitrogen in the soil decreased significantly at the highest loading (10\%), which might have contributed to the low soybean productivity. The low soil available $\mathrm{N}$ (Fig. 2) and low leaf SPAD values (low tissue $\mathrm{N}$ concentrations) suggested that nitrogen was probably immobilized at the $10 \%$ loading. Lower foliar nitrogen was also detected in biochar-modified tropical soils cultivated with rice and legumes (Lehmann et al. 2003). Short-term immobilization induced by biochar addition has been reported after laboratory incubations (Nelson et al. 2011; Bruun et al. 2012) and field trials on tropical nitrogen-deficient soils (Asai et al. 2009). In contrast, there have been fewer reports on biochar-induced short-term nitrogen immobilization in field or incubation experiments with temperate alkaline soil under semi-arid conditions. Another potential yield-inhibiting factor was that the $\mathrm{Na}^{+}$contents could have limited soybean growth at the $10 \%$ biochar loading. In this experiment, soil exchangeable sodium had a significantly negative correlation with soybean biomass production and yield parameters. Sodium is reported to be the most toxic ion for crops grown in weak alkaline soil and might account for the inhibition of crop growth at the 10\% biochar loading (Fortmeier and Schubert 1995). Biochar addition might have also increased soil salinity, as indicated by the high EC values (Fig. 1), especially at the highest biochar loading. Therefore, these negative factors should be considered when applying high biochar loading to saline-alkaline soil.

\section{Impacts of Biochar on Alkaline Soil Bulk Density, Porosity, and Water Holding Capacity}

Some incubation and field experiments have focused on the benefits of biochar when it is added to weathered, tropical, or subtropical soils that are characterized by poor fertility, low clay activity, and strong acidity. These soils are considered to be degraded soils. In contrast, the tested alkaline soil used in this study had poor soil structure with high 
alkalinity, high swelling pressure, and low hydraulic conductivity ( $\mathrm{Su}$ et al. 2018), which resulted in poor water physical properties. The results indicated that biochar application significantly increased saturated soil water content and water holding capacity after 5 months of incubation (Table 3). The results agreed with those reported by Xiao et al. (2016) for the semi-arid Loess Plateau. They reported that biochar application enhanced the soil permeability and water retention capacity of the mixed soil. The effects could be explained by the reduced soil bulk density (Busscher et al. 2010; Laird et al. 2010) and enhanced soil permeability (Hardie et al. 2014), which increased soil moisture retention (Liu et al. 2012a; Basso et al. 2013). Jeffery et al. (2011) reported that the water holding capacity increase after biochar addition was possibly the main contributor to overall yield improvements (Table 8). In this study, the reduced soil bulk density was related to the low biochar bulk density. Furthermore, the porous structure of biochar increased the formation of large macrospores around the biochar particles and prevented pores from clogging.

\section{Impacts of Biochar on Alkaline Soil Chemical Characteristics}

Numerous studies have demonstrated that biochar application could increase acidic soil $\mathrm{pH}$ values. In this study, the biochar-amended soils had lower $\mathrm{pH}$ values than the control treatment at the harvest stage, and the $10 \%$ biochar loading showed the largest $\mathrm{pH}$ decrease (0.24). Similar results were also reported by Zhang et al. (2019c) who revealed that biochar amendments had no impact on the $\mathrm{pH}$ value of the lou soil, but significantly reduced the $\mathrm{pH}$ value of the black soil, which taken from Daqing (Heilongjiang, China) with a higher background $\mathrm{pH}$ value than that of the biochar. The results were also consistent with a previous study that investigated on five types of alkaline soils (Liu and Zhang $2012 b$ ). The alkaline soil used in this study had high $\mathrm{Na}_{2} \mathrm{CO}_{3}$ and $\mathrm{NaHCO}_{3}$ contents. The addition of biochar promoted the conversion of $\mathrm{Na}_{2} \mathrm{CO}_{3}$ and $\mathrm{NaHCO}_{3}$ to neutral calcium salt, $\mathrm{CaCO}_{3}$, and $\mathrm{Ca}\left(\mathrm{HCO}_{3}\right)_{2}$. The decrease in soda salt $\left(\mathrm{Na}_{2} \mathrm{CO}_{3}\right.$ and $\left.\mathrm{NaHCO}_{3}\right)$ and the replacement of exchangeable sodium by exchangeable calcium decreased the $\mathrm{pH}$ value of the alkaline soil. Another reason for the $\mathrm{pH}$ decline was that acidic substances produced by the oxidation and decomposition of soil organic matter (Senesi and Plaza 2007; Dias et al. 2010) could neutralize soil alkalinity and lower the soil $\mathrm{pH}$ value (Zavalloni et al. 2011). The results suggested that applying low or intermediate biochar loading to slightly alkaline soil did not increase soil $\mathrm{pH}$. Therefore, adding biochar with a lower $\mathrm{pH}$ value than the tested soil at low or intermediate loading could potentially reduce the soil $\mathrm{pH}$ value.

Soil electrical conductivity (EC) is a method for measuring soil salt content and is a good indicator of nutrient availability, utilization efficiency, soil texture, and available water capacity. In this study, biochar application increased soil electrical conductivity, and the $10 \%$ biochar treatment significantly increased EC $26 \mu \mathrm{S} / \mathrm{cm}$. This result agreed with Hossain et al. (2011), who reported a significant rise in soil EC after biochar application. The high soil EC in biochar-modified soil might be related to the large amount of ash in biochar. Soil EC cannot directly measure specific ions or salt components, but it is associated with the nitrate, potassium, sodium, chloride, sulfate, and ammonia concentrations in total ash. Total ash contains nutrients that are beneficial to plant growth. However, it also contains high concentrations of salts that are harmful to plants, such as sodium ions.

Applying biochar increased soil total organic carbon content, which was positively correlated with the biochar loading. The increase in TOC content contributed to the high levels of organic matter in the biochar-amended soils. Biochar addition also enhances microbial activity and stimulates the decomposition of biological residues and biogenic 
humic substances, which promotes the formation of humus (Laird et al. 2009; Liang et al. 2010). The results also indicated that biochar addition increased the total nitrogen in biochar-amended alkaline soil. In addition to the nitrogen nutrients in biochar, another reason for the yield increases could be that biochar inputs increased the organic content of the tested soil (Cui et al. 2008). In this study, the C:N ratios in the biochar treatments were significantly higher than for the control treatment during the five growth periods. In particular, the $10 \%$ biochar treatment increased the C:N ratio $39 \%, 27.8 \%, 24.2 \%, 27.9 \%$, and $20.4 \%$ in the five growth periods, respectively. The higher $\mathrm{C}: \mathrm{N}$ ratios might have contributed to the decline in soybean yield at the $10 \%$ loading compared to the $5 \%$ treatment because available nitrogen declined at higher C:N ratios. Lehmann et al. (2003) and Chan et al. (2008) reported that increasing the biochar addition levels increased soil TOC content more than the soil total nitrogen content, which resulted in higher C:N ratios. This would cause nitrogen immobilization and lead to nitrogen deficiency. In this study, the detected decreases in soil available nitrogen content were highly correlated with the reduction in leaf SPAD values (data not shown).

Phosphorus and potassium are essential macro-elements for plant growth and development, and phosphorus availability is highly $\mathrm{pH}$-dependent. The tested soil was alkaline with a $\mathrm{pH}$ value of 8.25 , which would inhibit the availability of phosphorus. Furthermore, the tested soil had a higher total phosphorus content, but a lower available phosphorus content. The addition of biochar lowered the tested soil $\mathrm{pH}$ value (Fig. 1), which increased the content and availability of phosphorus in the modified soil during the different growth periods. Apart from the altered soil $\mathrm{pH}$ and direct release of phosphorus from biochar, biochar application also promotes microbial activity and therefore indirectly influences the mineralization of phosphorus (DeLuca et al. 2015). The results showed that there was a significant increase in available potassium in the alkaline soil after biochar addition. Incorporating biochar caused the available potassium to increase from 134.5 $\mathrm{mg} / \mathrm{kg}$ to $158.3 \mathrm{mg} / \mathrm{kg}$ at the highest biochar loading level during the harvest stage. This indicated that biochar application improved the availability of soil potassium, probably because biochar made from corn straw contained free nutrient cations (e.g., potassium) that did not volatilize (e.g., nitrogen) or exist in an insoluble form (e.g., magnesium) during the pyrolysis process. Furthermore, the potassium was preserved and converted to potassium salts, which are highly soluble, during the production of biochar (Karim et al. 2017). The increase in soil available potassium may also be due to short-term interactions and reactions between biochar and soil, such as dissolution and precipitation, adsorption and desorption, and redox reactions (Joseph et al. 2010). The same results were also reported by McElligott (2011), who found that biochar application increased the availability of soil potassium.

Cation exchange capacity is an indicator of the nutrient cation retention capacity when the nutrients are in a plant-available form, which is a form that prevents nutrient leaching losses (Sohi et al. 2009). In this study, biochar addition improved the CEC in biochar-modified soils compared to the control with no biochar addition, which was consistent with previous reports (Lehmann et al. 2003; Chan et al. 2008; Hossain et al. 2011; Major et al. 2012).

The application of biochar increased soil nutrient contents and CEC, but it also significantly increased the exchangeable sodium content, which had negative effects on plant growth, especially at the high biochar loading level. This result had rarely been reported in previous studies. Fortmeier and Schubert (1995) reported that sodium was the most toxic ion to crops grown in slightly alkaline soil. The increased exchangeable sodium content might account for the inhibition of crop growth at the $10 \%$ loading level. In 
addition, biochar addition had the potential to increase slightly alkaline soil salinity. The high EC values at the high biochar loading level suggested that this might have happened in the soils used in this study. Therefore, scientific attention should focus on amending saline-alkaline soil with the optimal biochar loading. This is important when biochars are used to ameliorate alkaline soils.

\section{Relationships between Soil Characteristics and Soybean Growth and Yield Parameters}

The correlation analysis results showed a relationship between soybean yields and the alkaline soil physico-chemical properties after 5 months of incubation. The enhanced yield was probably due to the improved soil physico-chemical characteristics. For example, a reduction in soil bulk density enhances water holding capacity (Liu et al. 2012a) and soil nutrients' status (e.g., soil organic carbon, and soil P and $\mathrm{N}$ contents). However, excessive biochar application inhibited soybean growth, which was observed in this study. The increase in the $\mathrm{C}: \mathrm{N}$ ratio after biochar application is often regarded as the main reason for soybean yield inhibition at high biochar loading levels because it leads to nitrogen immobilization (Lehmann et al. 2003; Rondon et al. 2007; Streubel et al. 2011). Table 8 shows that the soil $\mathrm{C}: \mathrm{N}$ ratio after biochar application was negatively associated with soybean height $(r=-0.529, p<0.05)$, seed number $(r=-0.721, p<0.01), 100$-seed weight $(\mathrm{r}=-0.723, \mathrm{p}<0.01)$, seed yield $(\mathrm{r}=-0.522, \mathrm{p}<0.05)$, and harvest index $(\mathrm{r}=-0.711, \mathrm{p}<$ $0.05)$. The increase in soil exchangeable sodium content is also regarded as a potential yield-inhibiting factor (Rajkovich et al. 2012). In this study, soil exchangeable sodium was negatively associated with soybean pod number $(\mathrm{r}=-0.814, \mathrm{p}<0.01)$, seed yield $(\mathrm{r}=-$ $0.632, \mathrm{p}<0.01)$, biomass $(\mathrm{r}=-0.428, \mathrm{p}<0.05)$, and harvest index $(\mathrm{r}=-0.591, \mathrm{p}<0.05)$. A pot experiment conducted by Rajkovich et al. (2012) suggested that the decline in plant growth caused by sodium may be explained by the significant increase in osmotic potential after biochar addition, which would reduce water uptake by the plant. In addition, available nitrogen (related to the $\mathrm{C}: \mathrm{N}$ ratio), soil $\mathrm{pH}$, and the soil exchangeable sodium percentage (related to exchangeable sodium) were also negatively correlated with soybean growth.

This short-term study revealed that a single application of biochar derived from corn straw could improve alkaline soil quality and increase crop productivity under the semi-arid soil incubation conditions used in this study. Corn straw biochar applications to the alkaline soil significantly improved soil physico-chemical properties, e.g., soil porosity, water holding capacity, and soil nutrients' status. The correlation analysis indicated that among the detected soil properties, nutrient content and soil water holding capacity were the main contributors to the increased soybean productivity, whereas increased nitrogen immobilization and exchangeable sodium content after biochar application inhibited soybean growth and yield parameters. This indicated that biochar had the potential to improve plant growth and soil properties in infertile alkaline soil. However, the negative effects should be taken into account when applying high biochar loading levels to alkaline soils. These results have important implications when using biochar to ameliorate alkaline soils. Additional field studies are still needed to further understand the impacts of corn straw biochar on soil physico-chemical characteristics and crop productivity under different conditions, such as different soil types, biochar types, loading levels, and fertilizer inputs. There is also a need for longer-term field experiments. 


\section{CONCLUSIONS}

1. Short-term single application of biochar positively and significantly improved quality attributes of the tested alkaline soil, increased soil water holding capacity, total organic carbon content, total nitrogen, Olsen-P, available potassium, and cation exchange capacity.

2. Single application of biochar enhanced soybean growth and yield components. The highest soybean height, biomass, and yield were obtained at the 5\% biochar loading level, but the benefits decreased when the biochar loading rate exceeded this threshold.

3. Negative effects should be taken into account when applying high biochar loading rates to alkaline soils.

\section{ACKNOWLEDGEMENTS}

This research was supported by the National Key Research and Development Program of China (Grant Nos. 2017YFD0101301; 2018YFD0300101; 2018YFD1000704) and the Project of Nature Scientific Foundation of Heilongjiang Province (Grant No. QC2017022).

\section{REFERENCES CITED}

Arif, M., Ilyas, M., Riaz, M., Ali, K., Shah, K., Haq, I. U., and Fahad, S. (2017). "Biochar improves phosphorus use efficiency of organic-inorganic fertilizers, maizewheat productivity and soil quality in a low fertility alkaline soil," Field Crop. Res. 214, 25-37. DOI: 10.1016/j.fcr.2017.08.018

Asai, H., Samson, B. K., Stephan, H. M., Songyikhangsuthor, K., Homma, K., Kiyono, Y., Inoue, Y., Shiraiwa, T., and Horie, T. (2009). "Biochar amendment techniques for upland rice production in Northern Laos: 1. Soil physical properties, leaf SPAD and grain yield," Field Crop. Res. 111(1-2), 81-84. DOI: 10.1016/j.fcr.2008.10.008

Baiamonte, G., De Pasquale, C., Marsala, V., Cimò, G., Alonzo, G., Crescimanno, G., and Conte, P. (2015). "Structure alteration of a sandy-clay soil by biochar amendments," J. Soils Sediments 15:816-824. DOI: 10.1007/s11368-014-0960-y

Bao, S. D. (2007). Soil Agro-Chemistrical Analysis, $3^{\text {rd }}$ Ed., China Agriculture Press, Beijing, China.

Basso, A. S., Miguez, F. E., Laird, D. A., Horton, R., and Westgate, M. (2013). "Assessing potential of biochar for increasing water-holding capacity of sandy soils," GCB Bioenergy 5(2), 132-143. DOI: 10.1111/gcbb.12026

Busscher, W., Novak, J., Evans, D., Watts, D., Niandou, M., and Ahmedna, M. (2010). "Influence of pecan biochar on physical properties of a Norfolk loamy sand," Soil Sci. 175(1), 10-14. DOI: 10.1097/SS.0b013e3181cb7f46

Bruun, E. W., Ambus, P., Egsgaard, H., and Hauggaard-Nielsen, H. (2012). "Effects of slow and fast pyrolysis biochar on soil C and N turnover dynamics," Soil Biol.

Biochem. 46, 73-79. DOI: 10.1016/j.soilbio.2011.11.019 
Chan, K. Y., Van Zwieten, L., Meszaros, I., Downie, A., and Joseph, S. (2008). "Using poultry litter biochars as soil amendments," Aust. J. Soil Res. 46(5), 437-444. DOI: 10.1071/sr08036

Chen, W. F., Liu, J., Xu, Z. J., Meng, J. (2012). “Combined biomass pellet carbonization furnace and a carbon production method thereof," China patent No. CN 102092709B

Cui, Z., Zhang, F., Chen, X., Miao, Y., Li, J., Shi, L., Xu, J., Ye, Y., Liu, C., Yang, Z., et al. (2008). "On-farm estimation of indigenous nitrogen supply for site-specific nitrogen management in the North China plain," Nutr. Cycl. Agroecosys. 81(1), 3747. DOI: $10.1007 / \mathrm{s} 10705-007-9149-8$

Delate, K., and Cambardella, C. A. (2004). “Agroecosystem performance during transition to certified organic grain production," Agron. J. 96(5), 1288-1298. DOI: 10.2134/agronj2004.1288

DeLuca, T. H., MacKenzie, M. D., and Gundale, M. J. (2015). "Biochar effects on soil nutrient transformation," in: Biochar for Environment Management: Science and Technology, J. Lehmann and S. Joseph (eds.), Routledge, London, England.

Dias, B. O., Silva, C. A., Higashikawa, F. S., Roig, A., and Sánchez-Monedero, M. A. (2010). "Use of biochar as bulking agent for the composting of poultry manure: Effect on organic matter degradation and humification," Bioresource Technol. 101(4), 1239-1246. DOI: 10.1016/j.biortech.2009.09.024

Farhangi-Abriz, S., and Torabian, S. (2018). "Effect of biochar on growth and ion contents of bean plant under saline condition," Environ. Sci. Pollut. Res. 5, 1-9. DOI: 10.1007/s11356-018-1446-Z

Fortmeier, R., and Schubert, S. (1995). "Salt tolerance of maize (Zea mays L.): The role of sodium exclusion," Plant Cell Environ. 18(9), 1041-1047. DOI: 10.1111/j.13653040.1995.tb00615.x

Glaser, B., Lehmann, J., and Zech, W. (2002). "Ameliorating physical and chemical properties of highly weathered soils in the tropics with charcoal - A review," Biol. Fert. Soils 35(4), 219-230. DOI: 10.1007/s00374-002-0466-4

Hardie, M., Clothier, B., Bound, S., Oliver, G., and Close, D. (2014). "Does biochar influence soil physical properties and soil water availability?," Plant Soil 376(1-2), 347-361. DOI: 10.1007/s11104-013-1980-X

Hossain, M. K., Strezov, V., Chan, K. Y., Ziolkowski, A., and Nelson, P. F. (2011). "Influence of pyrolysis temperature on production and nutrient properties of waste water sludge biochar," J. Environ. Manage. 92(1), 223-228. DOI:

10.1016/j.jenvman.2010.09.008

Jeffery, S., Verheijen, F. G. A., Van der Velde, M., and Bastos, A. C. (2011). “A quantitative review of the effects of biochar application to soils on crop productivity using meta-analysis," Agr. Ecosyst. Environ. 144(1), 175-187. DOI:

10.1016/j.agee.2011.08.015

Joseph, S. D., Camps-Arbestain, M., Lin, Y., Munroe, P., Chia, C. H., Hook, J., et al. (2010). An investigation into the reactions of biochar in soil. Aust. J. Soil Res. 48, 501-515, DOI: 10.1071/SR10009.

Karim, A. A., Kumar, M., Singh, S. K., Panda, C. R., and Mishra, B. K. (2017). "Potassium enriched biochar production by thermal plasma processing of banana peduncle for soil application," J. Anal. Appl. Pyrol. 123, 165-172. DOI: 10.1016/j.jaap.2016.12.009 
Lai, Y. H., Yang, X. L., and Fu, W. (2014). "Counter measure and suggestions for developing water saving and efficient agriculture in western semi-arid areas of Heilongjiang Province," Heilongjiang Agricultural Sciences 10, 149-151.

Laird, D. A., Brown, R. C., Amonette, J. E., and Lehmann, J. (2009). "Review of the pyrolysis platform for co-producing bio-oil and biochar," Biofuel. Bioprod. Bior. 3(5), 547-562. DOI: 10.1002/bbb.169

Laird, D. A., Fleming, P., Davis, D. D., Horton, R., Wang, B., and Karlen, D. L. (2010). "Impact of biochar amendments on the quality of a typical Midwestern agricultural soil," Geoderma 158(3-4), 443-449. DOI: 10.1016/j.geoderma.2010.05.013

Lal, R. (2006). "Enhancing crop yields in the developing countries through restoration of the soil organic carbon pool in agricultural lands," Land Degrad. Dev. 17(2), 197209. DOI: $10.1002 /$ ldr.696

Lehmann, J., Da Silva, J. P., Steiner, C., Nehls, T., Zech, W., and Glaser, B. (2003). "Nutrient availability and leaching in an archaeological anthrosol and a ferralsol of the Central Amazon basin: Fertilizer, manure and charcoal amendments," Plant Soil 249(2), 343-357. DOI: 10.1023/A:1022833116184

Lehmann, J., Gaunt, J., and Rondon, M. (2006). "Bio-char sequestration in terrestrial ecosystems - A review," Mitig. Adapt. Strat. Gl. 11(2), 403-427. DOI:

10.1007/s11027-005-9006-5

Liang, B., Lehmann, J., Sohi, S. P., Thies, J. E., O’Neill, B., Trujillo, L., Gaunt, J., Solomon, D., Grossman, J., Neves, E. G., et al. (2010). "Black carbon affects the cycling of non-black carbon in soil," Org. Geochem. 41(2), 206-213. DOI: 10.1016/j.orggeochem.2009.09.007

Lin, Q.Y., Zhang, L., Muhammad, R., Zhang, M. Y., Xia, H., Lv, B., and Jiang, C. C. (2018). "Assessing the potential of biochar and aged biochar to alleviate aluminum toxicity in an acid soil for achieving cabbage productivity," Ecotoxicology and Environmental Safety.161, 290-295. DOI: 10.1016/j.ecoenv.2018.06.010

Liu, J., Schulz, H., Brandl, S., Miehtke, H., Huwe, B., and Glaser, B. (2012a). "Shortterm effect of biochar and compost on soil fertility and water status of a dystric cambisol in NE Germany under field conditions," J. Plant Nutr. Soil Sc. 175(5), 698707. DOI: $10.1002 / j p \ln .201100172$

Liu, X. H., and Zhang, X. C. (2012b). "Effect of biochar on pH of alkaline soils in the Loess Plateau: Results from incubation experiments," Int. J. Agric. Biol. 14(5), 745 750.

Lu, R. L. (2000). Soil Agricultural Chemical Analysis Method, China Agricultural Science and Technology Press, Beijing, China.

Major, J., Rondon, M., Molina, D., Riha, S. J., and Lehmann, J., (2010). "Maize yield and nutrition during 4 years after biochar application to a Colombian savanna oxisol," Plant Soil. 333, 117-128. DOI: 10.1007/s11104-010-0327-0

Major, J., Rondon, M., Molina, D., Riha, S. J., and Lehmann, J. (2012). 'Nutrient leaching in a Colombian savanna oxisol amended with biochar," J. Environ. Qual. 41(4), 1076-1086. DOI: 10.2134/jeq2011.0128

McElligott, K. M. (2011). Biochar Amendments to Forest Soils: Effects on Soil Properties and Tree Growth, Master's Thesis, College of Graduate Studies, University of Idaho, Moscow, ID, USA.

Mia, S., Van Groenigen, J. W., Van de Voorde, T. F. J., Oram, N. J., Bezemer, T. M., Mommer, L., and Jeffery, S. (2014). "Biochar application rate affects biological 
nitrogen fixation in red clover conditional on potassium availability," Agr. Ecosyst. Environ. 191, 83-91. DOI: 10.1016/j.agee.2014.03.011

Nelson, N. O., Agudelo, S. C., Yuan, W., and Gan, J. (2011). "Nitrogen and phosphorus availability in biochar-amended soils," Soil Sci. 176(5), 218-226. DOI: $10.1097 /$ ss.0b013e3182171eac

Nishio, M., and Okano, S. (1991). "Stimulation of the growth of alfalfa and infection of mycorrhizal fungi by the application of charcoal," Bulletin of the National Grassland Research Institute 45, 61-71.

Novak, J., Busscher, W., Laird, D., Ahmedna, M., Watts, D., and Niandou, M. (2009). "Impact of biochar amendment on fertility of a southeastern coastal plain soil," Soil Sci. 174(2), 105-112. DOI: 10.1097/ss.0b013e3181981d9a

Quilliam, R., DeLuca, T., and Jones, D. (2013). "Biochar application reduces nodulation but increases nitrogenase activity in clover," Plant Soil 366(1-2), 83-92. DOI: 10.1007/s11104-012-1411-4

Rajkovich, S., Enders, A., Hanley, K., Hyland, C., Zimmerman, A. R., and Lehmann, J. (2012). "Corn growth and nitrogen nutrition after additions of biochars with varying properties to a temperate soil," Biol. Fert. Soils 48(3), 271-284. DOI: 10.1007/s00374-011-0624-7

Rondon, M. A., Lehmann, J., Ramírez, J., and Hurtado, M. (2007). "Biological nitrogen fixation by common beans (Phaseolus vulgaris L.) increases with bio-char additions," Biol. Fert. Soils 43(6), 699-708. DOI: 10.1007/s00374-006-0152-z

Senesi, N., and Plaza, C. (2007). "Role of humification processes in recycling organic wastes of various nature and sources as soil amendments," Clean: Soil, Air, Water 35(1), 26-41. DOI: 10.1002/clen.200600018

Singh, B., Singh, B. P., and Cowie, A. L. (2010). "Characterisation and evaluation of biochars for their application as a soil amendment," Aust. J. Soil Res. 48(7), 516-525. DOI: $10.1071 / \mathrm{sr} 10058$

Sohi, S., Lopez-Capel, E., Krull, E. and Bol, R. (2009). "Biochar, climate change and soil: A review to guide future research," in: CSIRO Land and Water Science Report 05/09, Commonwealth Scientific and Industrial Research Organization (CSIRO), Campbell, Australia, pp. 17-31. DOI: 10.4225/08/58597219a199a

Spokas, K. A., Cantrell, K. B., Novak, J. M., Archer, D. W., Ippolito, J. A., Collins, H. P., Boateng, A. A., Lima, I. M., Lamb, M. C., McAloon, A. J., et al. (2012). "Biochar: A synthesis of its agronomic impact beyond carbon sequestration," $J$. Environ. Qual. 41(4), 973-989. DOI: 10.2134/jeq2011.0069

Steiner, C., Teixeira, W. G., Lehmann, J., Nehls, T., De Macêdo, J. L. V., Blum, W. E. H., and Zech, W. (2007). "Long term effects of manure, charcoal and mineral fertilization on crop production and fertility on a highly weathered Central Amazonian upland soil," Plant Soil 291(1-2), 275-290. DOI: 10.1007/s11104-0079193-9

Streubel, J. D., Collins, H. P., Garcia-Perez, M., Tarara, J., Granatstein, D., and Kruger, C. E. (2011). "Influence of contrasting biochar types on five soils at increasing rates of application," Sci. Soc. Am. J. 75(4), 1402-1413. DOI: 10.2136/sssaj2010.0325

Su, C.-C., Ma, J.-F., and Chen, Y.-P. (2018). "Biochar can improve the soil quality of new creation farmland on the Loess Plateau," Environ. Sci. Pollut. Res. 26(3), 26622670. DOI: $10.1007 / \mathrm{s} 11356-018-3550-5$ 
Sun, G. Y., and Wang, H. X. (2016). "Large scale development to saline-alkali soil and risk control for the Songnen Plain," Resources Science 38(3), 407-413. DOI: 10.18402/resci.2016.03.04

Uzoma, K. C., Inoue, M., Andry, H., Fujimaki, H., Zahoor, A., and Nishihara, E. (2011). "Effect of cow manure biochar on maize productivity under sandy soil condition," Soil Use Manage. 27(2), 205-212. DOI: 10.1111/j.1475-2743.2011.00340.x

Wang, Z. Q., Zhu, S. Q., and Yu, R. P. (1993). Chinese Saline Soil, Chinese Science Press, Beijing, China.

Wu, X.-W., Wang, D., Muhammad, R., Zhang, L., Jiang, C.C. (2019). "Investigating the effect of biochar on the potential of increasing cotton yield, potassium efficiency and soil environment," Ecotoxicology and Environmental Safety .182: 1-7. DOI:10.1016/j.ecoenv.2019.109451

Xiao, Q., Zhu, L.-X., Shen, Y.-F., and Li, S.-Q. (2016). "Sensitivity of soil water retention and availability to biochar addition in rainfed semi-arid farmland during a three-year field experiment," Field Crop. Res. 196, 284-293. DOI: 10.1016/j.fcr.2016.07.014

Yamato, M., Okimori, Y., Wibowo, I. F., Anshori, S., and Ogawa, M. (2006). "Effects of the application of charred bark in Acacia mangium on the yield of maize, cowpea, peanut and soil chemical properties in south Sumatra, Indonesia," Soil Sci. Plant Nutr. 52(4), 489-495.

Zavalloni, C., Alberti, G., Biasiol, S., Vedove, G. D., Fornasier, F., Liu, J., and Peressotti, A. (2011). "Microbial mineralization of biochar and wheat straw mixture in soil: A short-term study," Appl. Soil Ecol. 50, 45-51. DOI: 10.1016/j.apsoil.2011.07.012

Zhang, M. Y., Muhammad, R., Zhang, L., Xia, H., Cong, M., Xia, H., et al. (2019a). "Investigating the effect of biochar and fertilizer on the composition and function of bacteria in red soil," Appl. Soil Ecol. 139, 107-116. DOI: 10.1016/j.apsoil.2019.03.021

Zhang, M. Y., Muhammad, R., Zhang, L., Xia, H., Zeinab, E., and Jiang, C. C. (2019b). "Response of fungal communities in different soils to biochar and chemical fertilizers under simulated rainfall conditions," Science of the Total Environment. 691, 654663. DOI:10.1016/j.scitotenv.2019.07.151

Zhang, M. Y., Muhammad, R., Zhang, L., Zeinab, E., and Jiang, C. C. (2019c). "Biochar induces changes to basic soil properties and bacterial communities of different soils to varying degrees at $25 \mathrm{~mm}$ rainfall: more effective on acidic soils," Frontiers in Microbiology. 10, 1-15. DOI: 10.3389/fmicb.2019.01321

Article submitted: July 26, 2019; Peer review completed: September 23, 2019; Revised version received: January 3, 2020; Accepted: January 6, 2020; Published: January 13, 2020.

DOI: 10.15376/biores.15.1.1463-1481 